Meta

Journal des traducteurs

Translators' Journal

\title{
A Marginal(ized) Perspective on Translation History: Women and Translation in the Eighteenth Century
}

\section{Mirella Agorni}

Volume 50, numéro 3, août 2005

Le prisme de l'histoire

The History Lens

URI : https://id.erudit.org/iderudit/011598ar

DOI : https://doi.org/10.7202/011598ar

Aller au sommaire du numéro

Éditeur(s)

Les Presses de l'Université de Montréal

ISSN

0026-0452 (imprimé)

1492-1421 (numérique)

Découvrir la revue

Citer cet article

Agorni, M. (2005). A Marginal(ized) Perspective on Translation History: Women and Translation in the Eighteenth Century. Meta, 50(3), 817-830.

https://doi.org/10.7202/011598ar
Résumé de l'article

$\mathrm{Au}$ dix-huitième siècle, la traduction était une activité prestigieuse en Grande-Bretagne. Elle comprenait deux secteurs bien distincts, selon les langues traduites : d'une part le latin et le grec, d'autre part les langues vivantes (français, allemand, italien et espagnol). Les classiques des littératures latine et grecque étaient le domaine des hommes, tandis que la traduction des langues vivantes représentait un des rares genres littéraires ouverts aux femmes. Parmi les exceptions significatives dans le domaine des classiques, nous analyserons le cas d'Elizabeth Carter (1717-1806), connaisseuse du grec et célèbre en tant que traductrice d’Épictète. Carter a développé une approche particulièrement originale de la traduction, basée sur une forme ingénieuse de collaboration protoféministe avec son amie Catherine Talbot (1721-1770). 


\title{
A Marginal(ized) Perspective on Translation History: Women and Translation in the Eighteenth Century
}

\author{
MIRELLA AGORNI \\ Università Cattolica del Sacro Cuore, Sede di Brescia, Italy \\ dsartori@sis.it
}

\begin{abstract}
RÉSUMÉ
Au dix-huitième siècle, la traduction était une activité prestigieuse en Grande-Bretagne. Elle comprenait deux secteurs bien distincts, selon les langues traduites: d'une part le latin et le grec, d'autre part les langues vivantes (français, allemand, italien et espagnol). Les classiques des littératures latine et grecque étaient le domaine des hommes, tandis que la traduction des langues vivantes représentait un des rares genres littéraires ouverts aux femmes. Parmi les exceptions significatives dans le domaine des classiques, nous analyserons le cas d'Elizabeth Carter (1717-1806), connaisseuse du grec et célèbre en tant que traductrice d'Épictète. Carter a développé une approche particulièrement originale de la traduction, basée sur une forme ingénieuse de collaboration protoféministe avec son amie Catherine Talbot (1721-1770).
\end{abstract}

\begin{abstract}
Translation was a prestigious activity in Britain in the Eighteenth Century, and the field was divided into two distinct areas: translation from the classics (focusing on Latin and Greek authors) which was a male-dominated territory, and translation from modern languages (French, German, Italian and Spanish) which was one of the few literary genres open to women. Yet, there were some significant exceptions in the area of the classics. I will analyze the case of Elizabeth Carter (1717-1806), the celebrated translator of Epictetus from the Greek, who developed a particularly original approach to translation, by adopting an ingenious form of proto-feminist collaboration with her friend Catherine Talbot (1721-70).
\end{abstract}

\section{MOTS-CLÉS/KEYWORDS}

women translators, feminist approaches to translation, Eighteenth-century translation, translation theory, translation of the classics

\section{The Status of Translators as Agents in Translation History}

Translators and their work occupy a central space in translation theory: in recent years translation studies has been increasingly drawing attention to their crucial mediation. Skopostheorie is a case in point. In spite of the fact that the communicative purpose of translation activities is the central preoccupation of this approach, Hans Vermeer has brought attention to the degree of freedom, on the one hand, and of responsibility, on the other, that bears on language mediators (Vermeer 1998: 54). Translators are presented as the experts who should design and implement those strategies which enable them to achieve their objective, i.e. their skopos. This line of thought takes translators to the centre of the stage, and yet it also involves a certain amount of risk: the notion of "accountability" is the other side of the coin, as translators may be

Meta, L, 3, 2005 
considered responsible for the consequences of their performance. Thus, it is no coincidence that ethical debates are flourishing in translation studies (Pym 2001; Chesterman 2001).

Translators' agency has become a key issue also in historical studies. The pivotal role of translators is the unifying criterion of Delisle and Woodsworth's (1995) seminal work on translation history: here translators are depicted as bearers of crucial historical developments, iconically represented in every chapter (significant titles include "Translators and the Development of National Languages" and "Translators and the Emergence of National Literatures," etc.). Taken together, these pictures build up a larger representation of history, as if in a mosaic, where every single component plays a fundamental role in the definition of the picture as a whole.

However, the extent to which historical cultural dynamics and discursive formation shape individual awareness, as well as any form of agency, has been brought to the fore by post-structuralist criticism, and has become especially problematic when it is connected with factors such as history and gender. Translators, like all other cultural mediators, are not fully autonomous, self-directing individuals, but negotiators and producers of discourse? Yet, at the same time, their agency is a product of such negotiations. By positing the existence of a dialectical relationship between translators and discursive dynamics, scholars do not rule out the notion of individual agency: on the contrary, it is by locating translator's work within a well-defined context (be it social, historical or cultural) that the material aspects of subjectivity are made evident. Rosi Braidotti speaks of the necessity of accepting the primacy of the bodily roots of subjectivity, and tries to define the subject's embodiment as a situated, partial location in a specific context. She refers to Donna Haraway's notion of situated knowledge, from the standpoint which "makes possible a vision of reality as a web of interconnected points, openings and moments of mutual receptivity that spin the web of social connectedness, communication and community" (1991: 271-2) - three factors which play a fundamental role in translation.

The politics of location is primarily linked to gender issues, implying an emphasis on the lived experience and embodied nature of subjects. In the Eighteenth century, women certainly exerted a considerable influence upon the evolution of several kinds of discourses, concerning literary production, education, religion, morality and probably to a lesser extent - translation. Nancy Armstrong has demonstrated that discourses of femininity were used instrumentally in the construction of a modern, moral form of subjectivity, in a historical period spanning almost two centuries, the Eighteenth and part of the Nineteenth (1987). The realm of the feminine appeared as an alternative form of power to that of money and rank, which were male-dominated: the new individual's value was represented in terms of her qualities of mind. Paradoxically, it was women's disenfranchisement from the dominant political order which made it possible for them to be molded into a model for the new, modern individual.

The metaphor of female exclusion lends itself powerfully to be used as a startingpoint for the development of new phenomena in historical narratives, and this mechanism can be seen at work also in the field of translation. I will argue that women's distance from the most prestigious discourses of translation in the Eighteenth century allowed them to produce new, creative thinking, generating original translating practices. 


\section{Women and Translation in the Eighteenth Century}

Although it is widely known that translation plays a crucial role at times of transition, the influence of this activity on the development of a new female literary voice in the Eighteenth century has rarely been analyzed (cfr. Agorni 2002; Ballaster 1992; McMurran 2000). ${ }^{1}$ The specific circumstances and constraints characterizing women's involvement in translation have received even less attention. One of the reasons for this neglect seems to be the derivative nature of translation, which has always been considered as a secondary activity in comparison with original writing. As a consequence, most feminist critics have paid more attention to those genres which were perceived as more empowering for women, particularly to the novel. Only a small number of literary historians working on the Sixteenth and Seventeenth centuries devoted their attention to the archeological task of rediscovering "lost" figures of women translators (Krontiris 1992; Patterson Hannay 1986; cfr. also Robinson 1995) - and unfortunately archeology shows its limitations in a historical period in which women (as well as men) only rarely put their names to this kind of work. ${ }^{2}$ What emerges from the small number of studies published in this field is a consideration of translation as a set of contiguous literary/textual practices, involving different forms of agency (embodied by translators themselves or translators' patrons, for example), each of them performing their own "project." 3 For instance, both Patterson Hannay and Tina Krontiris produce a close historical analysis of the works of both female translators and women patrons, who are sometimes one and the same person. An example is Mary Sidney, later Herbert (1561-1621), who acted as patroness of the arts, by gathering around her a group of notable poets, musicians, and artists. ${ }^{4}$ Krontiris argues that Mary Herbert used men as protective shields, exploiting them as public substitutes of her own creative self: she assigned translation tasks to male writers, and directed their work, asking them to do what she could have done better herself (1992: 67-8). In this way, female modesty was preserved, as her protégés created her public image, while she did not appear actively to seek fame. In the early modern period, women's role was much more prescribed than men's and specific historical pressures effectively shaped their involvement with the mechanisms of text production and reception.

It is my contention that the specificity of women's contribution to literary production may prove to be a remarkably fruitful ground for historical analyses of translation practices. A focus on gender enables critics to question the very definition of translation as a distinctive, unified category, by effectively bringing a set of collateral textual and social practices to the fore (such as proof-reading, giving directions on translating strategies, advice on publication, etc.), practices which ultimately explode the myth of translators as the sole directive agents in textual formation.

In Eighteenth-century Britain male translators were generally aware of their crucial role as literary mediators, but the same cannot be said about their female counterparts. One of the reasons for this was due to the fact that the prestigious works from classical languages were an exclusively male territory, as women did not have access to a formal education. As a consequence, their efforts were confined to contemporary European languages, and they produced translations of a secondary literary value, generally concentrating on ephemeral texts (translating novels, biographies, conduct literature, instructive manuals, travel accounts, etc). ${ }^{5}$ 
In this historical period even prominent literary figures such as Pope and Johnson dedicated part of their time to this activity, and developed an acute perception of the importance of their works, which belonged to a long and well-defined tradition. This increased their awareness of their translating choices and strategies, which were the subject of theoretical debate in the long prefaces to their works, and were often compared with the solutions adopted by their predecessors. ${ }^{6}$

Women rarely provided their translations with introductions or prefaces, and when they did so, they did it for reasons other than the celebration of a highly acclaimed literary tradition. They generally used paratextual apparata to lament the difficult personal circumstances which compelled them to take up this activity. For example, Mary Collier (?-1763), a translator from the French of Marivaux and the German of Gessner and Klopstock (cfr. Agorni 2002: 49-51), wrote a preface in which she maintained that she accepted the translation of Salomon Gessner's Death of Abel (1761) in order to gain the financial means to support her family. In her own words:

in order to contribute to the support and education of my children, I have taken up the pen. If I have attempted a task for which Nature never designed me, it is just that disappointment should teach me humility and wisdom. (Gessner: 1761: ii)

Such strategies were not used exclusively by female translators, but they acquired a special meaning in the hands of women, as they may be read as distinctive responses to a cultural climate that denied female self-expression.

Translations from modern languages did not occupy a significant place in the literary panorama of this historical period. They were rarely evaluated: critics and reviewers generally assessed them in terms of readability and fluency, but normally devoted greater attention to the subject of their originals. John Draper quotes a significant comment which appeared in the Monthly Review (1792), a periodical dedicating ample space to translation, in which a reviewer patently prioritizes the evaluation of the source text over that of its target version: "Reference must be had to the original author. His characteristical excellencies and defects being considered, the next object of enquiry will be, how far there is a possibility of equalling the one, and (provided fidelity will permit) of avoiding the other" (Draper 1921: 251).

And yet it was precisely the low status of translation from modern languages, with the precarious financial rewards that came with it, which allowed women to occupy a marginal position within the literary sphere. They made the best of it, so that they attracted the attention of (male) critics, who started to comment on the unprecedented dimension of women's involvement in translation. Attention was increasingly drawn to gender constraints, and this sometimes led to conventional misogynist remarks. ${ }^{7}$

In spite of a widespread negative reception of their works, women continued to be involved in translation in the course of the century, led by their desire to seek new means of financial support. The literary weight of the original and the possibility of strengthening their literary voice via translation were aspects which were hardly taken into consideration by them, as they were generally far beyond their control. Yet a few exceptional women did penetrate the male territory of translation from classical languages. Janet Todd $(1987)^{8}$ lists only two women translators from Latin in Eighteenth-century Britain: Susannah Dobson (?-1795) and Elizabeth Carter (1717- 
1806); in addition, Sarah Fielding translated Xenophon's Memoirs of Socrates from the Greek.

As has been said earlier, women were largely excluded from both methodological and theoretical discourses on translation, and yet, in spite of this, there were some noteworthy instances of women who translated classical authors.

\section{The Collaborative Efforts of Female Translators}

I would like to highlight the specific case of Elizabeth Carter, the best-known female translator in the Eighteenth-century, who worked out a very simple but formidable strategy: that of collaboration. Before making a historical analysis of her translation of Epictetus, however, it is worth examining in more detail this original approach to translation. Not only did this strategy allow Carter to discuss the methodological and theoretical aspects of her work in a very open way (and yet within the accepted scholarly discursive framework), but it also had a series of practical consequences on the realization and reception of this work. Firstly, from the beginning the project was conceived as a combined effort between two women, Carter herself and her friend Catherine Talbot (1721-70), and this guaranteed a high degree of support to the translator. Secondly, thanks to the intervention of her friend, Carter became involved with other people, who acted as patrons, experts in the field and "promoters," a small social network which eventually ensured the successful publication of this work.

Such a strategy effectively splits translation into a set of interconnected practices, and this is the point of my argument, that a historical perspective which pays special attention to gender issues is a particularly fruitful field of research on translation. Eighteenth-century women were far from developing a solid authorial stance; discourses of femininity which emphasized modesty and self-effacement seemingly worked to prevent their reluctance to be involved in an activity requiring, as Talbot puts it: "a care, a judgement, and exactness that original writings do not require, and some degree of humility in scarce aspiring to the name of an author." (Pennington 1808: 126).

The novelty of a collaborative, or cooperative approach to translation is all too evident, particularly in a century in which critical developments in the book trade and amendments to copyright laws were producing a redefinition of the cultural role of literary writers, opening the way to Romantic notions of authorship.

A translation perspective which stresses the importance of collaboration is a relatively new development even in contemporary translation studies. Skopostheorie, the theory of translational action, and other functionalist approaches to translation (most notably Christiane Nord's model) stress the collaborative aspects of the translation process, and outline the role of participants, such as initiator, commissioner, translator, user, message receiver, etc. In a contemporary society characterized by a high division of labour, translation is conceptualized as the work of social agents who must be more "in tune with each other" in order to achieve effective cooperation (Nord: 1997: 13). And it is precisely this term, cooperation, which has recently become a pivotal concept in the theoretical works of scholars such as Anthony Pym. He argues that long-term cooperation between cultures and the mutual benefits deriving from it (mutual trust in primis), are the principal objectives of cross-cultural communication. Hence, translators should find ways to promote cooperation, and 
here Pym envisages various scenarios, as translation is defined as "only one of the several available strategies for solving multilingual communication problems" (2000: 90). Other strategies may involve learning the other language, for example. The result of this approach is a redefinition of translation in economical terms, or, to put it more prosaically, in terms of its costs. ${ }^{9}$

The idea of translation as a collaborative effort has received special attention also by feminist scholars. As early as 1985 Myriam Diaz-Diocarez envisaged a type of cooperation between author and translator which has enabled the expression of a feminist perspective in the target language text (1985: 156). Collaboration is also one of the strategies exemplified by Françoise Massardier-Kenney in her systematic evaluation of contemporary feminist translation practices (1997). Although Massardier-Kenney questions the originality of current feminist strategies, novelty is not the point of her argument. Her objective is rather a reassessment of translation strategies in terms of their capacity to open up a space for a woman's voice; thus, she makes a distinction between two categories, namely "author-centred" and "translator-centred" practices, defined in the following way: "Author-centred strategies include recovery, commentary and resistancy; translator-centred strategies include commentary, use of parallel texts and collaboration" (1997: 58).

As I have pointed out elsewhere (Agorni 2000: 83) the strategic value of these definitions is immediately apparent, as they position women as text producers, either in their capacity of translators or authors. Hence, Massardier-Kenney's scope is no less than a feminist redefinition of translation agency. The compound "text producer" is a complex term which combines the idea of individual agency (i.e. the woman's author or the female translator's agency) and the cultural dynamics that have molded it. Moreover, by rejecting the traditional dichotomy between author and translator, and embracing instead the idea of a cooperative effort, feminist theorists gain an immediate perception of the social dimension of language and of the collective construction of meaning. As Massardier-Kenney puts it: "Collaboration with other translators emphasizes that meaning has to be constantly negotiated since the translators collaborating in the task are constantly comparing their interpretation of the same text" (1997: 65).

It is my contention that there are other, more creative ways to successfully realize feminist collaboration, which go beyond the cooperation between translators or between translator and author. Women translators, in the same way as any other agent in translation, have a crucial responsibility, as they do not limit themselves to reproducing translation discourses with their own practice, but actively contribute to shaping it. Traces of these negotiations in the past can be discovered through the analysis of contextualized translations, projecting "localized" or metonymical images of translation (Tymoczko 1999, 2000; Agorni 2002), which produce a marginal(ized), yet crucial, perspective on translation history.

\section{Elizabeth Carter: a Celebrated Woman Translator}

Elizabeth Carter was born in Deal, Kent, in 1717. Her father, the Reverend Nicholas Carter, taught her Greek, Latin and Hebrew, and encouraged her to study French and German. She developed an exceptional facility in language learning, and taught herself Italian, Spanish, Portuguese and Arabic. 
Far from opposing her advancement in the world of literature, her father actively encouraged it by introducing her to Edward Cave, who published the London-based periodical Gentleman's Magazine. Carter went to live in London at the age of twentyone and made friendships with a distinctive group of writers, both female and male, the most prominent figure being Samuel Johnson. Her first two translations were published during her early stay in London, the source texts being an essay from the French author Jean Pierre de Crousaz, published under the title An Examination of Mr Pope's Essay on Man (1738), and an Italian treatise by Francesco Algarotti, which was brought out in 1739 as Sir Isaac Newton's Philosophy Explain'd for the Use of the Ladies.

Carter went back to live in her hometown in Kent in 1739, and apparently withdrew from the literary scene for nearly twenty years. Yet her private correspondence with her friend Catherine Talbot, whom she met during a visit in London in 1741, illustrates her strong interest in classical and contemporary literature, as well as her single minded commitment to study. Encouraged and assisted by her friend Catherine Talbot, in 1749 Carter began to work on the translation which would bring her unprecedented fame for a woman in this historical period, that is her edition of All the Works of Epictetus, which was published in 1758. This work brought her financial security and social prestige: a few months after its publication she was introduced to Elizabeth Montagu, and became a familiar figure in literary circles such as the Bluestocking's and Mrs. Vesey's. Her last publication, a collection of poetry entitled Poems on Several Occasions appeared in 1762. She died in London in 1806 at the age of 88 .

Carter was one of the most acclaimed and learned women of this historical period: according to her biographer, her translation of Epictetus "made a great noise all over Europe." ${ }^{10}$ Queen Charlotte asked to be introduced to her in 1791 and King George visited her at her house in Deal in 1804 . Her characteristic combination of proverbial modesty and impressive scholarship made her into an inspirationsl figure for women and the possibility of considering Carter as a proto-feminist has been acknowledged by several scholars. ${ }^{11}$

\section{Carter's Translation of Epictetus}

Carter's translation of Epictetus (a Stoic philosopher of the $\mathrm{I}^{\text {st }}$ century AD) was not originally intended for publication, but was in fact embarked upon as a private project. Carter's intimate friend Catherine Talbot, who lived with the Bishop of Oxford's family, asked her to make the doctrines of Epictetus accessible to a large readership. Translation occupies a considerably large space in the correspondence between the two friends: they often discussed contemporary editions of classical literature, sometimes going into the details of sensitive aspects, as in the case in which they debate between themselves the impact of gender stereotypes in the translation of a speech by Pericles in a version by Thomas Hobbes. Here Catherine Talbot is discussing the English version of Thucydides' works, ${ }^{12}$ and writes to her friend:

I thought of him [Thucydides] just what you do, and over and above, I am very much offended with him on behalf of all the Grecian ladies, of whom he does not think fit to mention one through his whole history; and indeed of all ladies in general, to whom he gives a very civil admonition in one of Pericles' speeches, to keep themselves in quiet, 
and make themselves as little talked of as possible. I wish you would give me a politer translation of this passage than Hobbes has done. I got some gentlemen to look into the Greek, and they brought me a wicked note out of the old scholiast that makes everything ten times worse. (Pennington, 1808: 56-7).

In spite of the fact that translation was realistically perceived as a secondary literary activity, ${ }^{13}$ Talbot and Carter displayed an unusual awareness of its central cultural function. Not only did they recognize translation's primary role as cross-cultural communication, but they were also somehow conscious of the ethical dilemma of the translator, as someone who is asked to mediate the relations between source and target texts and cultures. The potential ambiguity of this mediation is not underestimated: on the contrary, the two women discuss both the translation's commitment towards the needs of the target culture (its regulatory function of introducing works produced by other cultural systems) and the ethical imperative to represent the source works in their own light (that is the problematic representation of the other). Carter's and Talbot's discussion of such delicate theoretical questions is expressed in the language of their time, as the following quotation demonstrates. The excerpt is taken from a letter Talbot wrote to Carter in 1747:

Well, to be sure a faithful and elegant translator is a character of the highest virtue in the literary republic. It implies public spirit the most void of ostentation; a kind regard for the illiterate; a love of our native country, shown by enriching its language with valuable books; a just regard for merit of whatever country, by placing the merit of some valuable foreigners in the truest and fairest light; a care, a judgement, and exactness that original writings do not require, and some degree of humility in scarce aspiring to the name of an author. But how few of those heroes and heroines are there! The common herd of translators are mere murderers. (Pennington 1808: 126).

It was in this climate that the project of translating such a complex author as Epictetus was conceived. As early as 1743 Talbot laments to her friend the fact that the works of the stoic philosopher were not available: she takes up the position of the excluded reader, who needs the expertise of a competent translator, and appears to be working out a peculiar form of cooperation. Only an unusual degree of collaboration between two exceptionally gifted women could have been the basis for such an ambitious project as the translation of Epictetus. Carter had exceptional linguistic and scholarly abilities, which were undoubtedly vital for the translation of such a difficult author; on the other hand, she lacked precisely those social and worldly-wise characteristics that were the prerogative of her younger friend, who lived in London and was the pupil and friend of bishops. ${ }^{14}$ Yet, Talbot's role in this project was not merely that of promotion; in spite of the fact that she herself was not proficient in the Greek language, she managed to secure the learned assistance of Thomas Secker, Bishop of Oxford. His contribution was systematically filtered by Talbot, who conveyed Secker's comments to her friend by means of an intimate correspondence. Apart from a very short direct epistolary exchange between Carter and the Bishop, Talbot took it upon herself to supervise the translator's work, by accurately and competently relaying the Bishop's words. The effect of this strategy is extremely interesting: on the one hand, the translator was effectively given the "professional" support she needed to accomplish her translating task; on the other, she felt so much at ease in corresponding with another (exceptional) woman, that she managed to overcome the Eighteenth-century female inhibition towards the theoretical discourse on translation. 
In her letters to Talbot, Carter gave vent to her own views, and went as far as to disagree with Secker on specific translation problems. The original, lively discussion which took shape in this correspondence represents a fundamental chapter in the history of translation theory; given gender configuration in this historical period, this is a notable achievement for Carter and Talbot.

As soon as Carter started working on her translation in 1749, a crucial topic of discussion emerged, concerning the style and tone to be adopted. Carter was in favor of a moderate transformation of the text into readable English, whereas the Bishop preferred a closer adherence to the style of the original. Secker's opinions were expressed by an intermediary: it was Talbot who communicated with the translator:

The Bishop of Oxford says your translation is a very good one; and, if it has any fault, it is only that of being not close enough, and writ in too smooth and too ornamented a style. Epictetus was a plain man, and spoke plainly; a translation that should express this would, he thinks, preserve more the spirit of the original, and give an exacter notion of it. (Pennington, 1807: 111).

Carter was not discouraged by this criticism, as long as she could count upon the judicious mediation of her friend, and sent back a candid reply: "I believe I had some important thing to say in defence [sic.] of my passion for ornament, and to have drawn in poor Epictetus to assist me" (112). However, the fact that this translation was not perceived as a private act of friendship, but, rather, as a serious intellectual enterprise, apparent through the solicitous concern of the Bishop, who did not give up his position regarding the style, and went as far as to add a few lines of his own to the following letter by Talbot: "Let me speak a word for myself: why would you change a plain, home, awakening preacher into a fine, smooth, polite writer, of what nobody will mind? Answer me that, dear Miss Carter" (112). Yet, Carter was not persuaded, and kept on defending her idea of making the text more accessible to contemporary readers; once again she wrote to her friend Talbot: "with regard to style, one certainly ought not to introduce tropes and figures which the author himself never dreamed on; but if the sense is preserved, it is not lawful to endeavour to make him speak such a language as will make him appear natural" (113).

The discussion took on an increasingly theoretical tone, and eventually culminated in Secker's formulation of a type of translation that contemporary translation scholars would define as "resistant," borrowing Lawrence Venuti's words (1995; 1998). A rather perceptive analysis of Epictetus' cultural role in the time he was living forms the basis of the Bishop's argument, but the theoretical model he appeals to is one which is extremely respectful of the linguistic and stylistic peculiarities of the source text, and yet, at the same time, effectively captures readers' attention. This time Secker spoke by himself:

[...] a translator should represent him in our tongue, such as he appears in his own: not indeed copying the peculiarities of the language he speaks in, but still preserving his genuine air and character, as far as ever is consistent with making him rightly understood. [...] every ancient writer should, in common justice, be laid before the modern reader, if at all, such as he is. And Epictetus, in particular should, because he will make a better figure, and have more influence in his own homely garb than any other, into which he may be transvesti [sic.]. (113-4).

The fact that Carter was openly recognized by Secker as his equal in this theoretical discussion is evident in its conclusion, when the Bishop envisages a "middle-way" 
solution between his own and Carter's translating strategy: "I confess myself to have bent the stick as strongly as I well could, the opposite way to yours. But I am content to divide the difference with you; which, perhaps, after we have both explained ourselves, will be no great one" (114). ${ }^{15}$

Carter's translation was a long, painstaking process, spanning the years 1749-1758. The translator was living in relative obscurity in her hometown in Kent, making a few occasional visits and short stays in London. In the meantime, her friend Talbot was drawing up a plan to have the translation published; thanks to the support of a large number of influential friends, publication by subscription became a realistic possibility. Also in this case, an effective form of cooperation was essential: proposals of publications were circulated among friends, and when a sufficient number of subscribers had signed up (with payment of a small amount or of all of the cost) the work could go in press.

In view of the impending publication, Carter and Talbot undertook the task of editing Epictetus, providing the translation with introduction and notes. It was a collaborative effort, as it was carried out in the same way as the translation had been. Talbot's role was no secondary one: as early as 1753 she started planning, or rather directing, both form and content of the preface:

When this main matter is done, it will perhaps be time enough to think of some kind of prefatory discourse, for the information of us uniformed readers, giving such accounts as can be best collected of the life and character of Epictetus, and the plan of the stoick [sic.] philosophy, in doing which, or in your notes, you will have good opportunities to work out those points in which it is false, wild, and defective, and to draw comparisons between that and the only true philosophy the Christian. (Pennington 1808: 340).

At first, Carter did not sound enthusiastic about providing her translation with a paratexual apparatus, ${ }^{16}$ and eventually she revealed her reservations: she found that her friend's criticism on stoic philosophy was too harsh. As Harcstark Myers argues, Carter's study "had taught her to look at cultures other than her own in a dispassionate way" and believed that the Christian religion "could rest on its own advantages, without denigrating heathen morality." (1990: 167). Carter's actual words reveal a high degree of confidence and a subtle annoyance - elements which would not have escaped to her in an unmediated correspondence with the Bishop:

In general, I believe it is scarcely ever of any use, and perhaps very seldom right, to depreciate the heathen morality. Wise and good men in all ages, who sincerely applied their hearts to the discovery of their duty, cannot, I think, be supposed in any very material instances to have failed, though they had neither a proper authority nor could promise sufficient encouragement to qualify them for effectual instructors of the multitude of mankind. The Christian religion has peculiar and distinguished advantages enough of its own to prove its divine excellence to every unprejudiced mind, and on these we may safely rest our case, even if we grant everything to the heathen morality which its most zealous admirers can demand. (Pennington 1808: 400).

The result of this frank disagreement between the two friends was a new awareness of the problems of representing the Other, even in such a delicate field as religion. Also in this case, the two women were rather self-consciously trespassing the boundaries of Eighteenth-century gender configuration, by entering a debate on heathen morality. The fact that Carter had to give up her position, and eventually accept the necessity of producing a paratextual apparatus according to Talbot's instructions, 
comes as no surprise, considering the fact that this translation was published under the auspices of a Bishop. ${ }^{17}$ Carter did produce a preface illustrating the shortcomings of Epictetus' philosophy, in comparison with the superior worth of the Christian religion. ${ }^{18}$ Yet, at the same time, she managed to find a small space for "vindicating" the Greek author, speaking on behalf of the value of Stoicism in the past, and the importance of an accurate representation of it in the present. Harcstark Myers quotes a significant passage from Carter's introduction:

Their [the Stoics] Doctrine of Evidence and fixed Principles, was an excellent Preservative from the Mischiefs, that might have arisen from the Skepticism of the Academics and Pyrrhonists, if unopposed: and their zealous Defence of a Particular Providence, a valuable Antidote to the atheistical Scheme of Epicurus. [...] Even now, their Compositions may be read with great Advantage, as containing excellent Rules of Self-government, and of social Behaviour; of a noble Reliance on the Aid and Protection of Heaven, and of a perfect Resignation and Submission to the divine Will: Points, which are treated with great Clearness, and with admirable Spirit, in the Lessons of the Stoics; (Epictetus: xxvi; quoted by Harcstark Myers 1990: 167).

\section{Conclusion}

Carter's translation, published with her name on the title-page, was an enormous success. As I noted in the short biographical note, it brought her both celebrity and financial security; she was judged to be one of the most learned women of all time, and included in several anthologies of works by "eminent ladies." ${ }^{19}$ Moreover, her translation remained the standard English version of Epictetus for a long time. ${ }^{20}$

Talbot's name, on the other hand, was almost immediately forgotten after her death in 1770, and nowadays it appears exclusively in bio-bibliographical sources of Eighteenth-century women or in studies on the Eighteenth-century epistolary genre. Yet, her role in this translation goes beyond any form of traditional patronage. It is safe to conclude that the translation of Epictetus would not have seen the light of day without her invaluable contribution.

However, my point is not that of drawing attention to the fundamental role of women's friendship in certain historical periods (although we must concur with Massardier-Kenney that collaboration is indeed a felicitous feminist strategy of translation); I would prefer to sum up very briefly by referring to the advantages of a gender perspective on translation history. As I have sought to emphasize, this kind of research is particularly arduous, for a number of reasons not least because women (in common with many men) did not publish their translations under their names, and rarely stepped into the forbidden territory of translation theory.

Yet, it is just such a lack of "primary" historical sources that works as an incentive for critics to take into account secondary, marginal(ized) sources, such as private letters, reviews, and biographical material (autobiographies, memoirs, etc.). Researchers become particularly aware of the fact that the theoretical discourse on translation was produced under a myriad of different circumstances, which go well beyond the publication of more or less authoritative prefaces or treatises.

A fundamental consequence of this perspective is that it sheds light on distinctive and unusual forms of agency in translation: collaboration effectively explodes the notion of translation as a unitary activity, breaking it down into a set of parallel practices and corresponding roles - those of translating, editing, promoting, but also 
mentoring, supporting the translator, and so on. Not only does this perspective emphasize the notion of the negotiability of meaning and interpretation, as MassardierKenney (1997) has argued, but it also demonstrates that the roles and activities involved in translation are also essentially negotiable, in a very creative way. This is the most important insight that Talbot's and Carter's case passes on to us in the present.

\section{NOTES}

1. Rose Ballaster investigated the influence of French literature on the novels of early Eighteenthcentury women such as Aphra Behn (1640-89) and Delarivière Manley (1663-1724), who produced translations and adaptations from this language (1992: 42-60).

2. Another problem is illustrated by the fact that the identification of a work as a translation is particularly difficult in the early modern period, as the dividing line between translation, adaptation and original production was extremely fine. As Mary Helen McMurran puts it: "adaptation did not necessarily look different from literal, accurate translations of prose fiction in the 18th century." (2000: 87).

3. Following Berman, I intend this term in the sense of a composite, articulated objective, dictated both by the position of the translator and the specific claims of the work which is to be translated (Berman 1995: 76).

4. Mary Herbert's works include a composite edition of her brother Philip Sidney's Arcadia, translations of Garnier's tragedy Antoine (1592), Duplessis-Mornay's Discours de la vie et de la mort (1592), Petrarch's poem Trionfo della morte, and a few original poems.

5. For a general survey of translations produced by Eighteenth-century women in Britain see Agorni 2002.

6. For example, Pope cited John Dryden's work on Virgil in the preface of his translation of Homer's Iliad (1715-20), where he declared his intention of following in his predecessor's footsteps by choosing a translation strategy which was somehow in between literal translation and free imitation. Cfr Steiner (1975).

7. It is the case of Elizabeth Helme's translation of François le Vaillant's Travels from the Cape of Good Hope (1790), a travelogue which included plates illustrating the situations described by the narrative. Dorothy Blakey points out that some images had been "adapted" to the sex of the translator. Reviewers writing in the Monthly Review (Sept. 1790) remonstrated, claiming that readers had been "defrauded under the plea of female delicacy" (Monthly Review, Sept. 1790, cit. Blakey 1939: p. 38; cfr. also Agorni 2002: 48).

8. Todd's Dictionary of British and American Women Writers 1660-1800 (1987) is the only bio-bibliographical work on early women writers to draw attention to women's translation.

9. In Pym's own words: "the effort invested in the translation should logically not exceed the mutual benefits to ensue from the transaction" (2000: 189).

10. Carter's nephew and biographer, Montagu Pennington, published her Memoir a year after her death (1807), and edited her correspondence with her friend Catherine Talbot, as well as her letters to Mrs. Montagu, publishing two volumes in 1808 and 1817 respectively.

11. Most notably, Moira Ferguson (1985) and Katherine Rogers (1982) dedicate ample space to her life and works in their anthologies of feminist writing in Eighteenth-century Britain.

12. Cfr. Thomas Hobbes, Eight Books of the peloponnesian Warre Written by Thucydides...Interpreted... by Thomas Hobbes (London: 1629).

13. In 1745 Talbot wrote to Carter: "few clever people will deign to employ themselves in making translations, and if they would favour the world with making originals one would never complain of them" (Pennington 1808: 67-8).

14. Catherine Talbot and her mother lived with the Bishop of Oxford, Thomas Secker, and his wife. As the couple was childless, they developed a particularly affectionate relationship with Catherine, who was educated as Secker's heir. A frequent visitor of this household was Martin Benson, Bishop of Gloucester, who was Mrs. Secker's brother. For further information on this topic see Harcstark Myers 1990.

15. Carolyn Williams left us a vivid account of Carter's translation strategy: "To her eternal credit, Carter abandoned her ladylike scruples and gave the world a translation that conveyed, as faithfully as contemporary notions of decency would permit, Epictetus' abrupt manner, his predilection for 
concrete references and imagery, his penchant for blistering personal insult, and his reckless disrespect for persons" (1996: 19).

16. In March 1755 Carter wrote to Talbot: "Whoever that somebody or other is who is to write the Life of Epictetus, seeing I have a dozen shirts to make, I do opine, dear Miss Talbot, it cannot be I" (Pennington 1808: 382).

17. Harcstark Myers points out that "The subscription list reflected a variety of supporters; the presence of nobility and a large number of bishops suggests the influence of the Bishop of Oxford" (1990: 168).

18. The following remarks by Carter demonstrate her awareness of the constraints regulating the publication of her work: "However we may disagree in some particulars about Epictetus, I entirely approve the pointing out in the notes the absurdity of many of the principles, and the infinitely superior excellence of the Christian doctrines. I am extraordinarily obliged to the Bishop of Oxford and you for the admirable remarks you have been so good as to send me, and which, if the book is ever published, will make the most valuable part of it." (Pennington, 1807: 137).

19. Cfr. for example Ballard (1752).

20. In 1927 W.A. Oldfather defined Carter's translation "a very respectable performance under any conditions, but for her sex and period truly remarkable” (Oldfather: 15, quoted by Harcstark Myers, 1990: 169).

\section{REFERENCES}

Agorni, M. (2002): Translating Italy for the Eighteenth Century: British Women, Translation and Travel Writing, Manchester, St Jerome.

Armstrong, N. (1987): Desire and Domestic Fiction: A Political History of the Novel, Oxford, Oxford U.P.

Ballard, G. (1752): Memoirs of Several Ladies of Great Britain, who Have Been Celebrated for their Writing or Skill in the Learned Languages, Arts and Science, London, Newbury.

Ballaster, R. (1992): Seductive Forms: Women's Amatory Fiction from 1684 to 1740, Oxford, Clarendon Press.

Berman, A. (1995): Pour une critique des traductions: John Donne, Paris, Gallimard.

Blakey, D. (1939): The Minerva Press 1790-1820, Oxford, Oxford Bibliographical Society at the University Press.

Braidotti, R. (1991): Patterns of Dissonance, transl. by E. Guild, Padstow, Politi Press.

Chesterman, A: "Proposal for a Hieronymic Oath," The Translator, spec. issue 7, p. 129-154.

Delisle, J. and J. Woodsworth (eds.) (1995): Translators Through History, Amsterdam \& Philadelphia, John Benjamins.

Diaz-Diocarez, M. (1985): Translating Poetic Discourse: Questions on Feminist Strategies in Adrienne Rich, Amsterdam \& Philadelphia, John Benjamins.

Draper, J.V. (1921): “The Theory of Translation in the Eighteenth Century," Neophilologus 6, p. 241-254.

Ferguson, M. (ed.) (1985): First Feminists: British Women Writers 1578-1799, Bloomington, Indiana U.P.

Gessner, S. (1761): The Death of Abel in 5 Books: Attempted from the German of Mr Gessner, [transl. by M. Collyer], London, Dodsley.

Harcstark Myers, S. (1990): The Bluestocking Circle: Women, Friendship and the Life of the Mind in Eighteenth-Century England, Oxford, Clarendon Press.

Krontiris, T. (1992): Oppositional Voices: Women as Writers and Translators of Literature in the English Renaissance, London \& New York, Routledge.

Massardier-Kenney, F. (1997): “Towards a Redefinition of Feminist Translation Practice," The Translator 3, p. 55-69.

McMurran, M.L. (2000): “Taking Liberties: Translation and the Development of the EighteenthCentury Novel,” The Translator 6, p. 87-108.

Nord, C. (1997): Translation as a Purposeful Activity: Functionalist Approaches Explained, Manchester, St Jerome.

Olohan, M. (2000): Intercultural Faultlines: Research Models in Translation Studies I: Textual and Cognitive Aspects, Manchester, St Jerome. 
Patterson Hannay, M. (1986), ed: Silent but for the Word: Tudor Women as Patrons, Translators and Writers of Religious Work, Ohio, Kent State U.P.

Pennington, M. (ed.) (1807): Memoir of the Life of Mrs Elizabeth Carter with a New Edition of her Poems, London, Rivington.

Pennington, M. (ed.) (1808): A Series of Letters Between Mrs Elizabeth Carter and Miss Catherine Talbot from the Year 1741 to 1770, 2 vols., London, Rivington.

Pym, A. (2000): “On Cooperation," in Olohan (2000), p. 181-192.

Рyм, A. (2001): "Introduction: The Return to Ethics in Translation Studies," The Translator, spec. issue 7, p. 129-138.

Ribeiro, A. and J. G. BAsker (eds.) (1996): Tradition in Transition: Women Writers, Marginal Texts, and the Eighteenth-Century Canon, Oxford, Oxford U.P.

Robinson, D. (1995): "Theorizing Translation in a Woman's Voice: Subverting the Rhetoric of Patronage, Courtly Love and Morality," The Translator 1, p. 153-75.

Rogers, K. (1982): Feminism in Eighteenth-Century England, Brighton, Harvester Press.

Steiner, T.R. (1957): English Translation Theories 1650-1800, Amsterdam, van Gorcum.

Todd, J. (ed.) (1987): A Dictionary of British and American Women Writers 1660-1800, Rev. ed., Totowa, NJ, Rowman \& Littlefield.

Tүмосzко, M. (1999): Translation in a Postcolonial Context, Manchester, St Jerome.

Tүмосzко, M. (2000): "Translation and Political Engagement: Activism, Social Change and the Role of Translation in Geopolitical Shifts," The Translator 6, p. 23-47.

Venuti, L. (1995): The Translator's Invisibility: A History of Translation, London \& New York, Routledge.

Venuti, L. (1998): The Scandals of Translation: Towards an Ethics of Difference, London \& New York, Routledge.

Vermeer, H. (1998): “Starting to Unask What Translatology is About," Target 10, p. 41-68.

Williams, C. (1996): "Poetry, Pudding and Epictetus: The Consistency of Elizabeth Carter," in Ribeiro \& Basker (1996), p. 3-24. 